University of Montana

ScholarWorks at University of Montana

Numerical Terradynamic Simulation Group

Publications

Numerical Terradynamic Simulation Group

$5-1994$

\title{
Validating Diurnal Climatology Logic of the MT-Clim Model Across a Climatic Gradient in Oregon
}

Joseph Marion Glassy

The University of Montana

Steven W. Running

University of Montana - Missoula

Follow this and additional works at: https://scholarworks.umt.edu/ntsg_pubs

Let us know how access to this document benefits you.

\section{Recommended Citation}

Glassy, J. M. and Running, S. W. (1994), Validating Diurnal Climatology Logic of the MT-CLIM Model Across a Climatic Gradient in Oregon. Ecological Applications, 4: 248-257. doi:10.2307/1941931

This Article is brought to you for free and open access by the Numerical Terradynamic Simulation Group at ScholarWorks at University of Montana. It has been accepted for inclusion in Numerical Terradynamic Simulation Group Publications by an authorized administrator of ScholarWorks at University of Montana. For more information, please contact scholarworks@mso.umt.edu. 


\title{
VALIDATING DIURNAL CLIMATOLOGY LOGIC OF THE MT-CLIM MODEI ACROSS A CLIMATIC GRADIENT IN OREGON'
}

\author{
JOREPH M. GLASSY AND STEREN W. RuRNING

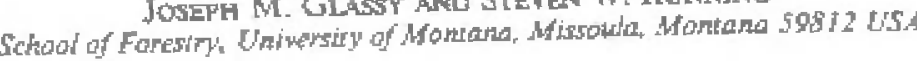

chstract. This study tests djumal etimatology assumptions made in the MT-CLIM roodel by examinins two microclimate wariables driven by dinmal atmosplieric tymanies: incideth solar radiation (in kilojoules per square metre), and humidity, expressed as vapor prossure deficit. VPD (in kilopaseals). The relative VPD thanidity comparison was used to test our hypothesis that night minimum temperatures cath funetion as a sumogate for dew-point temperatures. YPD was chosern as the humidity measure for these tests fince plants are more direcly sensitive to this measure thard relative humidity. For the obserwed Ys. estrimated vapor pressure deficit madels, we obtained coefficienus of determinanion $\left(R^{2}\right)$ ranging from 0.66100 .84 . Incident spiar radiation is calculated in the model using an algorithrn that relates diumal temperature amplitude to atmospheric transmissivity, cou. pled with a potential radiation model to compute difiuse and direct radiation. Comelations for incident solar fadiation models indicate generaily good agrement, with coefficients of determination Fanging frots $R^{2}=0.82$ to 0.89 . These results suggest that MT-CLJM tnay be a useful way to prowide the clinatology that many ecological/hydrological models require, particularly for larper scale spatiat modelins applications where precise metcotology may not be is important as a good general characterization of the regional climatology.

Key ward: elimale gradien of the Oregon Careade Range; climalological parameters divrnat

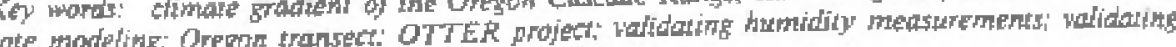

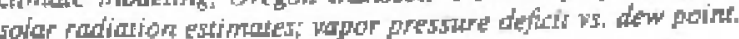

\section{INTRODUGTION \\ Climatology data requirements for ecologicai models}

Chimalology data play a critical role in regional and global-scale tocsystern applications. In a review of climalt information needs for ecologieal effects models. Petr (1950) describes 19 contemporary models. includine biomedevel, ecosystem process, species dyrimics, individual-tтee, and agricultural models, that all require basic meterohogical datz. Examples of such applications include hydroecologic models (Band and Wood 1988 , Band et al. 199 ly, grassiand thodels such as CENTURY (Paron et al, 1988), and forest and biome ecosystem process models (McMurtric I985. Runring and Coughlan 1988, Running et al. 1989, Agren el al. 199 I, Running and Gower 1991 j. To expioit ctirent remote sensing and geographical information system (GLS) approaches, many coosystem modes are evolving from one- to two-dimensional applications (Nemani et al. 1993), encouraging the tevelopment of better methods to tenerate climate surraces. These modeling approaches spad a large tange of spatial and temporal scales, emphasizin the breadth of the climatological data requirement. Climatological

\footnotetext{
"Manuseript received 24 August 1992 revised 25 Mareh 1993: accepred 5 April 1093. final verston reccived l May 1993
}

paranters required by these nodels typically include air temperature, soliar radiation, some measute of altmospheric humidity, precipitation, and in some cases, wind speed and direction. Meteorology data sets available for ecological models are available in matry diverse forms. Projtct-specific on-site data from portable meleorology ștations is ayailable, as wetl as more-loglized archives such as the USDA Fortst Service Remote Aulomated Weather Stations (RAWS) network Warten and Vance 1981 ). Lother term meteorological data aquilable includes arcbived hisiorical weather data sets such as the Clinatological Data Summaries maintained by the National Oreanic and Atmospheric Administration (NOAA), at the Natigra: Cimatic Data Center (NCDC, Ashivilie, North Carolina), werived from U.S. National Weather Service (NWS) stations.

The awality of available meteorological data varies. ensiderably, with problems ranging from missing values to erroneous dala collected by poorly calibrated or taulty instruments. An equally serious problem is that in som castes variables of interest to ecological modelers, such as incident solat radbation afd hunidity, are simply not collected at all.

The MT-CLIM approach of using 24-h minimum emperalure as a surrogate for dew point temperature attempts to address these defrciencies; the ability to lurther establish the strength and theoretical Iitmitations of this relationship is important in light of the 
relatively smalt fraction of established weather strations that colles himiơity measurements bf any kind. Runrine et al. (1987) estimated that the densily of prinary (NWS) stations recording humidity (as well as solar radiation) in any form was <1 station $100000 \mathrm{~km}^{2}$ throughout the western United States. The ctallenge for many ecosystem modelers is to mateh the qualithtive and quanitative requirements of their models with the sparial and temporal seales of the various climatological data sources availabie. NWS Daily CtiInatological Summaries represtrt a dependibie data source when good on-sile wether data cannot be colfected and NOAA weather satellite data are too codrse. However, the only wariables routinely archived at bouh primary and secondary NWS șites are daily maximum and minimum air temperature (uken at $L .4$ m above the ground) ant precipitation. Dew point temperatwre medsurements are taken, however, at some primary NWS sites, usually sittated at major airports. Although originally intended to work using MWS station Datly Climatological Summary data, the MT-CLIM model may be driven using any weather station scuro that provides maximum and minimum temperatures and precipilarion. Primary inputs to MT-CLIM inciude base station latitude, base station clevation, and site clevation, aspect, slope, albedo, atrotpheric transmissivity, base and site precipitation isohyers, and temperpture lapse rates (Table 1), Slandard MT-CLIM outpus include daily mieraclimate valtes for arr temperature (site temperature, and $24-h$ maximum and minimum temperatures, in degres Celsius), incident solar radiation $(400-2500 \mathrm{~nm}$ wavelengths, in kilojoules per squart metre per day), relative humidity (in percent) and precipitation (in cenlimeres) in moustaimous terrain.

In response to the paucity of site-specife climatology sath tequired for eoological process models, Running et ail. ( 1987 ) derised a mountain microtinate simulatot, the MT-CLIM thodel. MT-CLIM evolved from two earlier research madels, H20TRANS and DAY TRANS (Ruming 1984), which evaluated the ecosystend-level siprificance of stomatal control mechanisms (transpiration and water stress) at hourly and daily time steps. IEspectively. MT-CLIM is composed of two types of climatology logic, the topographic elimatology that spatially extrapolates meteoroiogical conditions into complex temain, and the diumal climalology that derives additional meteoralogical information from the input datn (Huggerford ct al. 1989). In the topographic section of MT-CLIM daily data from primary NWS weather stations is extrapolated to nestby sites. adjusting for the fifferteces in aspect, teration, sloper and yegetation type between the site of interest and one ar two base weather stations.

A key assumption in the development of the MTCLIM logic, and one that distioguishes it from other metcorological models, is the concept of operational enviromment whereby importan environmental rari-
TARIE I. Example of MT-CLIM inputs (for WASA OTIER project MTT-CLIM model validauon): Cassode Head. Sile l.

\begin{tabular}{|c|c|}
\hline $\begin{array}{l}\text { Input } \\
\text { txam- } \\
\text { ple }\end{array}$ & Input choices and/or calegorits \\
\hline 5 & 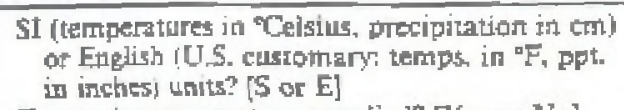 \\
\hline $\mathbf{N}$ & Dew paint ismperatlire supplied? [Yes or $\mathrm{No}$ ] \\
\hline 1 & $\begin{array}{l}\text { Number of ppl. staulons? [l or 2] J/2 then we } 2 \\
\text { isohyeus below }\end{array}$ \\
\hline \multirow{3}{*}{$\mathrm{N}$} & Use thresho]d rediation? [Yes or No] \\
\hline & $\begin{array}{l}\text { Use yearday [dry of year) ith place of morthlh-and- } \\
\text { day? [ret or No] }\end{array}$ \\
\hline & Input variableas* \\
\hline 208 & $\begin{array}{l}\text { No. of days } \\
\text { Latizude (degres) }\end{array}$ \\
\hline 49.03 & $\begin{array}{l}\text { Lanizude (degres) } \\
\text { Site elevation (melted for Sl ar (cet for English) }\end{array}$ \\
\hline 49.0 & Base elevation (metress for SI or feel for English) \\
\hline 1250 & $\begin{array}{l}\text { Site aspect. } 0 \text { to } 350 \text { degrets }(0=\text { Norh; } 1.80= \\
\text { South }\end{array}$ \\
\hline 100 & Sile slope (pertent) \\
\hline 6.3 & Site LAI liea a arta index, all \\
\hline 2.0 & Site isohyel (precipization) \\
\hline 2.0 & Buse isohyer scation I \\
\hline 0.0 & 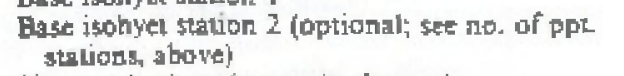 \\
\hline 1.0 & Site east horizon (cxtent in degres) \\
\hline 10 & Site west horizon (extent in detres) \\
\hline 0.16 & Stte albedo $(0.2=20 \%)$ \\
\hline 0.60 & TRANCF (sea level atmospherte hransmissiyily) \\
\hline 0.45 & $\begin{array}{l}\text { IEMPCF (lemperafure cortelion for sine ap- } \\
\text { pmatimation) }\end{array}$ \\
\hline 6.377 & Thmperature lapae rate (diprees/l $000 \mathrm{~km}$ ) \\
\hline 7.288 & $\begin{array}{l}\text { Lapse race for maximum temperature (depres } \\
\text { IDOD km of (t) }\end{array}$ \\
\hline 3.644 & $\begin{array}{l}\text { Lapse rale for minimum temperalure idegrees } \\
1000 \mathrm{kml} \text { or } \mathrm{th}\end{array}$ \\
\hline 2.730 & $\begin{array}{l}\text { Detw point temperature lapse rate (degrees' IOQ0 } \\
\text { km or ft) }\end{array}$ \\
\hline
\end{tabular}

* No. of days is integer wariable; all the rest are real numbers.

ables are defined on the basis of plane physiology rather than only meteorologically (Mason and Lagentheim 1957, Waringet al. 1972, Waring and Schlesinger 1985). For example, dsy length can be defined in the MTCLIM model in terms of the period when the light cormperstation poin ( $\left(10 \mathrm{w} / \mathrm{m}^{2}\right)$ lor conifer needles is exeeded-the point as which conifer stomatal opening, transpiration, and positive tret photosynthesis begins. In isctgular or complex topography, this definition of day leogh may be $20 \%$ shorter then the full periad from sunrise to suntet (Runating el al. 1987). This threshold may be adjusted for other species as well.

The diurnal climatolagy in MT-CLIM generates two particularty problematic climetological parameters required by ecosystem jracess models-inctient solar radiation (Runnirg E: al, 1587) and a humidily measure useful from a plant physialogy standpoint (Grantz 1990y. For this study our objexctive was to test key assumptions in the MT aCLM rnodel diutinat clima tology logic by comparing incident solar radiation and relative humidities measured at five Oregon Transect 
Tmills 2. Suminary of key parameters of the QTTER (Orcgon Transect Eeosysterns Research) siteg.

\begin{tabular}{|c|c|c|c|c|}
\hline \multirow[b]{2}{*}{ Site name } & \multicolumn{2}{|c|}{ Meleorolocical station } & \multirow[b]{2}{*}{$\begin{array}{l}\text { Physiographic } \\
\text { province }\end{array}$} & \multirow{2}{*}{$\begin{array}{l}\text { Mean leat } \\
\text { area index } \\
\text { (LAI) }\end{array}$} \\
\hline & $\begin{array}{l}\text { Eleration } \\
\text { (m) }\end{array}$ & Location & & \\
\hline $\begin{array}{l}\text { Cascade Head } \\
\text { Waring's Woods } \\
\text { Scio } \\
\text { Sanuam Pars } \\
\text { Metcolius }\end{array}$ & $\begin{array}{r}49 \\
60 \\
335 \\
1500 \\
1027\end{array}$ & 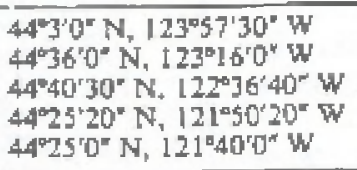 & 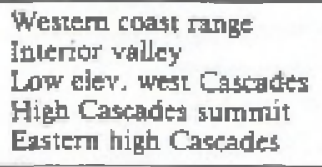 & $\begin{array}{l}6.4 \\
5.3 \\
8.6 \\
2.8 \\
2.0\end{array}$ \\
\hline
\end{tabular}

Ecosystem Researth (OTTER) yites against MT-CLIM estimations of these parameters.

\section{METHODS}

This stcudy wats conducted as part of the National Aeronautics and Space Administration (NASA) Oregon Transect Ecosystem Research (OTTER) project (Peterson and Waring 1994 [this issue]). The OTIER projed inclides six primary sites atong a 250 -km eastwest trabsect through central Orgon at $44^{\circ}$ norh latitude, with elevations ranging from sea levei to 1500 m. A timely opporturity to further validate basic assumptions in the MT-CLIM model was presented since each of the five stain OTTER sites wiras equigped with a porable weather station (Campbeil Scientific Logan. Utah, USA. Incident solar radiation was recorded at each OTIER sile using a LI-COR Li220S pyranomeIer, sensitive to radiation at $400-2500 \mathrm{~nm}$ wavelengths. Relative humidity (RH) was recorded using a PCRC55 humidity sensor (Campbell Scientific). Al cach OTTER site during 1989 and 1990 hourly measurments of 13 meteorological variables were collected, imcludimg minimum and maximum temperature, rehative frumidity, and incident solar radiztiom; the daily dita set we used was prepared from this hourly data set. In this dan set daylight is defined as the full period from sunrise to sunst. Key site parametes for the five OTTER sites used in this study are preserted in Table 2. Only sites with metenology stations were used for this study; the tastemmost site (Juniper) relied on the meteorology station at the Metolius site. For a more complete description of OTTER site chstacteristics, refer to Ruryom et al. (1994) and Gowird et al. (1994) [this issue].

The observed data for this study were obtained from the Forest Science Data Base (FSDB) maintained by Oregon State University as part of the Long Term Ecological Researeh (LTER) data holdings. Daily obser- vation data from 1989 and 1990 were extracted from the daily meteorological data set. Our goal was to assemble as close to a full annual data sequened as possible, both to ensure an adequnte sample size and to reveal any terts in the data that might have been. phenologically driven. Several cate mnges of observed dats were excluded for four of the five sites (all sites but Santiam Pasg) due to known calibration problems witb the RH sensors. Table 3 contins a description of the date ranges and total number of days used is this analysis. Daylight is defired within the LTER datibase as the time from sunrise to sunget. and so the model was set to match this definition of day length. The sine rariables used were 24-h minimum and maximum nir temperature (in destees Celsius), daylight awerase relative honmidity (in percent), total incident solar radiation (in kilojoules per square ritetre per day), and precipitation (in militimetres per day).

\section{Humidity and vapor pressure defictir}

There are several common ways of expressing humidity, including vapar fensity, relative humidily (RH), and Mapor pressure deficit (VPD). Vapor density is simply the ruass of water vapor in a unit volume of air and is also knowr as absolite humidity (Oke 1987). The most commonly collected humidity mosarte, relative htmidity, is defined as the actual mointure content of a parcel of air as a percertige of that coutained in the same volume of saturated air at the same temperature (Barry and Chorley 1987). Dew-poitht temperature, another index of humitity, is the tetnperailure at which saturation owcurs if air is cooled at constant pressure without addition or removal of vapor (BarTy and Chorley $\$ 987)$. The relative humidity varies inversely with ternperature during the day, tending to be lower in the early aftemoton and higher at night. Whier the RH is look the air temperature and dew-point temperature are equal. Yapor pressure is a measure of

TAgls 3. Seasonal ditribution of date ranges and totat nurnter of days used in this analysis, by sine (Cregon, USA).

\begin{tabular}{|c|c|c|c|}
\hline Silı & 1989 days & 1990 days & Total days \\
\hline $\begin{array}{l}\text { Cascade Head } \\
\text { Warins"s Woods } \\
\text { Scio } \\
\text { Sartiam Pass } \\
\text { Matelius }\end{array}$ & $\begin{array}{l}7 \text { Jur-31 Dec } \\
28 \mathrm{May}-31 \mathrm{Dec} \\
28 \mathrm{May}-31 \mathrm{Dec} \\
26 \text { Jur-5 Now } \\
5 \mathrm{Jur}-31 \mathrm{Dec}\end{array}$ & $\begin{array}{l}\text { Jan-31 May } \\
\text { I Jan-31 Mar } \\
\text { I Jan-31 Mar } \\
9 \mathrm{May}-25 \mathrm{Nav} \\
\text { I Jan-31 Mar }\end{array}$ & $\begin{array}{l}359 \\
308 \\
308 \\
334 \\
299\end{array}$ \\
\hline
\end{tabular}


lhe partial pressure excrted by water yapor molectles in the air (Oke 1987). The siluration vapor pressure deficit of an air parcel is the difference belween the foturation vapor pressure and the actual vapor pressure. In an exological context, YPD may be the most useitul measure of humidity, as it represents a measure of the drying power of aip, playing an imporant part in determining the relative rates of transpiration in plants (Montcith and Unsworth 1990).

To tegt the MT-CLIM diumal humidity logic, VPD was chosen as a humidity measure as opposed to RH since plants physiologically respond mare readily to fiuctuations in VPD ban to changes in RH (Grantz 1990). Ecological process variables dependent on VPD include evapotranspiration (ET), stomatal conductance, pholosynthesis (PSN) dyramics, and plant water relations. VPD also plays a key role in stomatal conductances (Gates 1980, Jarvis and Morison J98I, Fricnd 1991) and in plant water flow resistances (Hum tal 1991). Running et al. (1987) reported an $R^{2}$ coefficient of 0.85 for the relationstip between dew point temperature and 24-h minimum temperalure for three stands in the Lubrecht Experirantal Forest in westem Montana; in the same study, he also reported $R^{2}$ coefficients for relative humidity algorithms of $0.59,0.43$, and 0.60 for thre wertem. Montana drainages.

Measuring humidity dependably over time has always been a challenge to meteorologists tue to the calibration, reliability, and longevity problems that humidity instrumerts are subject 10. When a given set of meteorological dati is obtained. it is trelpftul to know the type of humidity-sensing instrument used; unforturately, this information is not always available in the data set documentation. In gerseral, laboratory quality dew point hygrometers are more accurate (Okt 1987). Unforunately lheir expense, power requirement5, and the mecessity [or periodic calibration tends to limit their use to primary NWS (National Weather Serwice) weather staticns. The leșs expensive humidity instruments are based on chemingl or electrical sensors where the humidity is measured on the basis of charges in chemical substrate or electrical properties due to moisture absorption; these lypes tend to be the mosi prone to degradation problems. In the OTJER study, for exanple, within several months of initial installation the digital RH sensors at alt sites except the Santiam site exhibited a premature signal degradation. seriously compromistnis the data's usefulness (Goward et al. 1994 [this issuel). The degradation problem was diagnosed th terms of RH trends at the afected sites increasingly departing from expected diuntal recovery leveis. Field conditions apparemily caused some physjcal loss of the RH sensor substrale over time, restiling in a systentanic reducuion in sensilivity and signal gain. This problem necessitated additional sereering and verification of the measured relative humidity data from all sites but the Santiam Pass sile:

For this analysis we used daylight arerage relalive

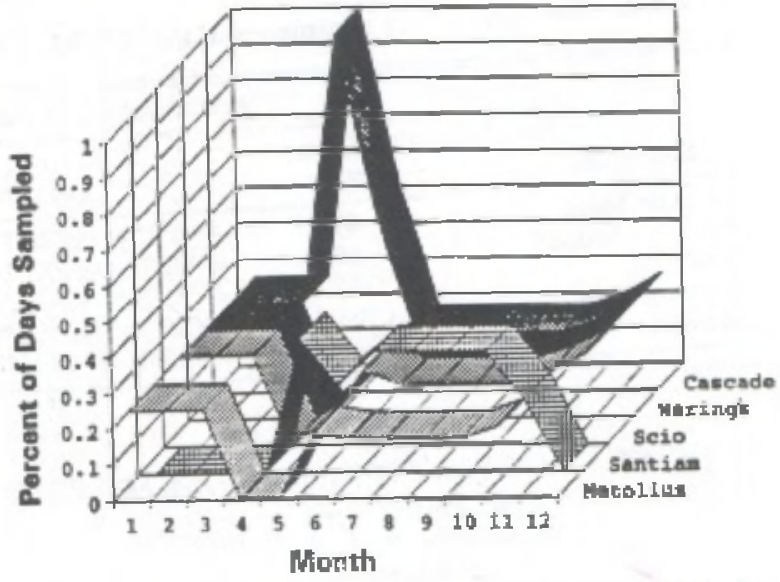

Fig I. Frequencies of days sampled by month for two sample years (1989 and $2990 \%$, by OTTER site.

humidily; only contiguously sequenced dsys with no missing values for temperature, radiation, of precipitation qqualifed for inclusion in the analysis dala set. We specifically excluded observations where the day fill within a time perion where the RH sensor for the site was known to have degraded. Adequate ample sizes were thus obtained by using qualifying data from both 1989 and 1990 (Fig. $L$, as a result of these exclusions, contiguous 365-d sequences for egch site were not posibible.

The MT-CLIM model estirnates site relative humidity and vapor pressure defteits using a scheme whereby dew-point Iemperature is used in Muray's (1967) formulation:

$$
\text { esd }=0.61078 \cdot e^{\left[\frac{1+34 \cdot r_{2}}{237.3 * T_{2}}\right]}
$$

where esd is saturated yapor pressure (in kilopascals) and $T_{\text {sue }}$ is ayerage daylight site temperature lin degres Celsius?:

$$
e=0.6107 .8 \cdot e^{\left[\frac{17.269 \cdot T_{m}}{237.3+T_{1 m}}\right]} \text {, }
$$

where es is ambienl vapor pressure (in kilopascals) and $T_{\text {Dew }}$ is der-point temperature (in degres Celsius), and

$$
\mathrm{RH}_{\text {Site }}=\left[\frac{\mathrm{es}}{\mathrm{est}}\right] \cdot 100,
$$

where $\mathrm{RH}_{\mathrm{su}}$ is the daylight average site relative thumitity (in percent).

Two forms of these equarions were used to produce the "observed" VPD ws the "estinated" VPD, differing only in the way that ambient vapor pressure (es) was compuled. To produce the observed VPD, saturated vapor pressure (esd) was computed exactly as show in Eq. I and the site ambient vapor pressure was computed using a simple algebraic transform of the RH equation (Eq. 3) 


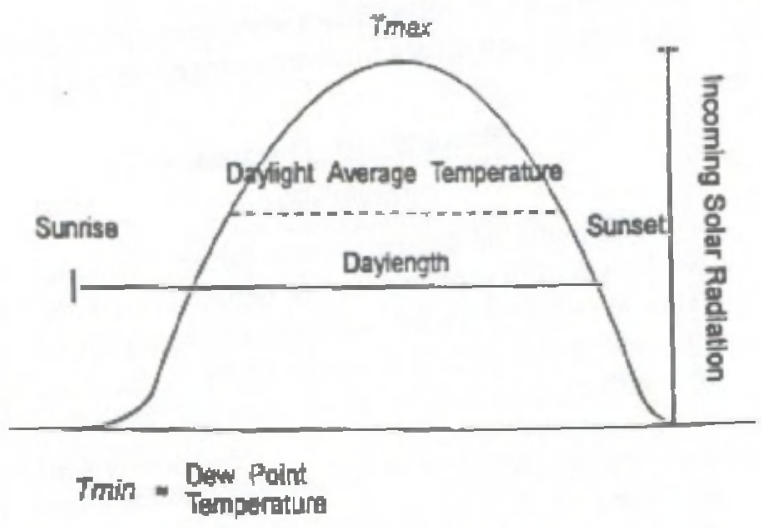

Fic. 2. Diagram of MT-CLIM diural iofict illustrating the retationship of diurral minimum and Traximum temperarter, incoming solar radiation, and the trunested period defining taylight averama temperature.

$$
\mathrm{es}=\frac{\mathrm{RH}_{\mathrm{Obs}}}{\mathrm{j00}}
$$

where $\mathrm{RH}_{\mathrm{O}}$ is the measured dayight a verage $\mathrm{RH}$ (in percont) at the bast station.

Vapor pressure deficit is defired simply as the difference between saturated and ambient vapor pressures. VPD = esd - es (Oke 1987 , Monteith and Unsworth 1990). To compute the "Artinated" VPD for each site, ambient vapor pressure (es) was computed using Eq. 2 substituting the night minimum ternperature for dow point temperatunc. Saturated rapor pressure (esd) was computed for lhe estimated VPD in the usual way as in $\mathrm{Eq}_{\mathrm{q}} 1$.

\section{Incident solor tadialion}

The method MT-CLIM uses for computing solar radiation on the site is adapled from the methods of Bristow and Campbell ( 1984 ) and is driven solely by diurnal temperature amplitude, freenig it from the requirement of historically questionable cloud-cover estimates. Our hypothesig that ditural air-temperaiore amplitude (Fig 2) rejates directy to incident solar Tadiation loading assumes a thorzontally stable gunosothere over the region of idterest, with no significant advective exchange. To the extent that stable conditions dominate, the model should perfon farity well. One implication of this diumal tenperature approsech is that the performance of our model in estimatiog solar radiation is crinically dependent on the many ways in which air masses may be horizonually modified; an air mass may be heated from beious either by passing from a cold to a warm surface or by solar hearing of the ground over which the air is locsted (Bary and Chorley 1987). When significant horizontal gir movement does occur, the difering temperatyres and energy exchange properties of these masses cam disproporionately' control air temperatures and thus mask or override the more diect influence of solar radiaxion. weskeming the mpdel's performance. Topoeraphically driver phe momena such as cold air drainages, frost pockets, and physiographic fommations that generate or amplify local winds con txer a similar effect. Syrnoptic-scale frontal systems, local kemperature inversions, and extrentIy metic environments where latent heat exchange dampens the diumal temperature amplitude present additional meteorological phenomena that the Bristow and Campios (1984) based approach cannot accommodate well.

The daily 24-h average incident solar radiation ralues measured ar cach of the five OTTER situs were compared directy against the MT-CLIM estimated values, using the total incident solar radiation (24 k) as the observed dath. Incident folar raciation at each. site was computed in MT-CLMM using the algorithms docymentet in Runing et al. (1987) requiring only observed daily minimum and maxirhum tomperatures. Clear sky transmissivity was firt enmputed, assuming a value of 0.60 for mear sea level, incressing by 0.008 $\mathrm{u}^{-1}$ wh elevation. Fral atmospheric unasmissivity was then computed as a function of diumal temperature ampintwde, following the Itethod of Brisow and Campoell (1984). The logic tehind this retationstuip is that the total transmittanes for a gived day includes both direct and difise components incidert on a horizontal surface, and therefore integrates the atmospheric attenuation coefficients implicitly (Bristow and Campbell 1984). Next, a potential radiatior model adapted from Gamier and Ohmura (1968) and Swift \{1976) was used to thleulate direct and diftuse sotar ridiation, anjusting for slope and aspect and trubcating the direct bean solar irradianee by the east and west horizon of the site. The final estimate of incoming solar radiation to the site was then eomputed as the aboveatmosphere radiation reduced by the atmospheric transmittance.

The diumal temperature range, $\Delta T$, is calculated by the equation:

$$
\Delta T_{Y D}=T_{\max }-\frac{\left[T_{\operatorname{minY}}+T_{\mathrm{tminY}}+\mathrm{HL}_{1}\right]}{2},
$$

where YD is the yearday index (day of year $=1 \ldots$ 365), $T_{\max }$ is the daily maximum temperature (in deftes Celsius), $T_{\text {minut }}$ is the daily mininum temperature (in degress Celsius), and $\Delta T_{\mathrm{rO}}$ is range in daily temperature extrens:

The relationship betwecr diumal temperature amplitude and atmospheric transmitune is calculated uning the Bristow and Campoell (1984) Hormulation:

$$
\tau_{t}=A\left[1-e^{\alpha-B \Delta T^{c}}\right],
$$

where $T_{\text {, }}$ is the daily total transmittance, $\Delta T$ is the daily range of air temperature, and $A$ is the maximum clegr sky trangmiltance, $B(-0.0030)$, and $C(2,4)$ are empirica! constants that determine how sotur $r_{f}$ is achieved as $\Delta T$ incteases. The $B$ and $C$ constants reptestent the partitioning of entrgy characterishic of the modeled 
site, Although these have historically been fixed at the above values for all sites, furt ture revisions of MT-CLIM should incorporate a better stuategy for delermining the seasonal site characteristics driving this relationship.

The equation used to compute potential incoming radiarion is:

$$
Q_{s}=\mathrm{Is}_{s}+D_{s}
$$

whers $Q$, is the total incoming radiation on a slope (in kitojoules per square metrel at the Earhts surface, Is, is the direct beam radiation on a slope at the Eanh's sutrlace, and $D_{k}$ is the difiuse radiation at the surface; the direct beats radiation is at the surface is calculated by:

$$
\mathrm{Is}_{s}=\cos \phi\left(R_{\mathrm{o}} N \cdot \tau_{t}^{(\mathrm{AM})}\right)
$$

where $R_{0}$ is the solar constanl (in kilowits per square metrey abowe the atmosphere as a monthy average, $N$ is the sine interal for calculation in seconds, $\tau_{f}$ is the daily tolal tratismituance from Eq. 6 . and AM is the

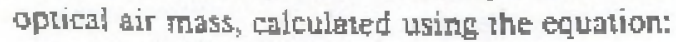

$$
A M=\left[\frac{1.0}{\cos \theta}\right]+1.0 \cdot 10^{-1}
$$

wherc cos $\theta$ is the cositie of the zenith angle (sec Running et al. [1987] for more detailsi).

\section{Simudiom and analyrig}

Two sets of MT-CLIM simulations were run to generate observed and predicted walues using versions of MT-CLIM in which the humidity algorithms were modified as discussed above. The observed solar radiation values (as 24-h averages) used were the origina) values measured at each of the five sites with the $1220 \mathrm{~S}$ pyranometer mounted an porthble weacher stalions. The first set orsimulations produced the observect VPD values for each of the frue sites, and the second set of simulations producet the estimated VPD ralues and estimated incident solar radiation values for each of the five sites

Sereral statistics were used to evaluate algorithm performance, includimg the coefficient of determination $\left(A^{2}\right)$, the bet and $y$ intercept lincar regression coefticients, and the root mean square error, RMSE. The RMSE provides an indication of curve fit accuracy; with obscred yalues close to estimated ralues resulting in a lower RMSE. The RMSE is a conservative error measure that tends lo penalize large individual errors herivily (Rejcosky et al. 1989). Standard Lwotailed hypothesis tests of the model beta $\left(j_{1}\right)$ coulli aientc $\left(H_{0}: p_{4}=0, H_{*}: \theta_{1} \neq 0\right)$ and $y$ intercepts (using. the same two-tailed tests) were employert to further investigale the strength of the fitted models. Lastly, $F$ staitislic and t stalistic probability values were calculated to evajuate the overall quality of the linear re- gression models. All statistics were comptated using the SPS5/PC+ statistical software package (Norusis J988).

\section{RESULTS AND DISCUSSION Humidiry}

Coelficients of determination for the observed vs. predicted VPD (Yapor pressitre deficil) models ranged from $R^{2}=0.66$ to 0.84 , whth $F$ statistics significant at the 001 probabitity level, with three of the five sites $R^{2}$ coefficienis $>0.80$. This suggests that the VPD ap proach yields acceptable resulus owerall, persicularly in light of a pooled site VPD $R^{2}$ of 0.72 . Am examimation of normal $P$-P plots indicaled no serious departures. from normality, and plots of cascwige standardized residuals ws. fitted values indicated no obvicus patters in error trends. There was a silight clustering trend in $R^{2}$ coefficients, with the wetter, more productive sites (Cascade Head anci Scio) having the lowe corrlations $\left(R^{2}=0.65\right.$ and 0.68, respectively) and the other siles' $R^{2}$ values ranging from 0.80 to 0.83 (see Table 4). The distribution of point values for most sites was sliphtly skewed, doe in part to a slightly asymmetric sampling distribution seasonaly (Fig. I). Regression model slopess for the VPD models ringed from a low slope of 0,72 al the middle elevation, productive Scio site to a high slope of 1.5 at the cool, moist Cascade Head site (Fig. 3). VPD regression $y$ interepts ranged ftom 0.13 to $0.31 \mathrm{kPa}$, which in conjunction with the positive slopes contributed to a slight trend towards overoredtction. The Santiam Pass VPD retression model, where of served data did not require screening, may represent a useful average case of MT-CLIM's humidity performamce" the refession slope tor this site was 1.001 with a $y$ intercept of $0.31 \mathrm{kPa}$ (Fig-4). In general, MT-CL.MM somewhiat owerpredicted WPD across all sites except Scio.

In this study where the emphasis was on testing the diumal logic of MT =CLIIM the "base station" site characteristics were idenical to the "extrapdated" sites: corretions for changer in aspect elevation, or slope were therefore nol tequired. When the extrapolated site does markedly differ in uspect, elevanion, and slope from the base station site, it is posstble for the MT CIIM model to slighty over- or tuderestimate air temperatures at the target site, due to the way the algorithms extrapolate the base station daily $T_{\max }$ and $T_{\text {ratm }}$ temperatures to the new site characteristics. Such errors in estimated air temperature, if present, would naturylly affect the VPD estimates. For protess nodel depending or these humidity estinates, this would likely result in somewhat bighet transpiration rates and altered soil-water dyTamics. Limited a vaijability of tependable humidity or dew-point temperature daua for ecosystem research applications appears to justify further efforts to stremgthen the MT-CLIM approach. Better correction logic, howewer, still heeds to be developed to accommoiate the meteorological conditions 
TARLE 4. Solar radiation and YPD aha]ysis summary.*

\begin{tabular}{|c|c|c|c|c|c|}
\hline Sile & $R^{2}$ & SE $y^{\prime}$ & RMSE & Retrersion model & $N$ \\
\hline \multicolumn{6}{|c|}{ [ncident solar radiation relalionships (ndiation in $\mathrm{kJ} / \mathrm{mm}^{2}$ ) } \\
\hline Cascade Hend & 0.83 & 2873.5 & 3267,5 & $y=0.792(x)-657.4$ & 359 \\
\hline Waring's Woods & 0.89 & 30.33 .9 & 957.9 & $y=1.054(x)-1499.8$ & 308 \\
\hline Scio & 0.88 & 2736.5 & 4498.3 & $y=0.806[x]-1763.8$ & 308 \\
\hline Santian Pass & 0.94 & 3881.4 & ]6]9.4 & $y=1,048(x)-2302.1$ & 334 \\
\hline Metolitus & DAs & 4134.6 & 1667.5 & $y=1.010(x)-18048$ & 299 \\
\hline All sites pooled & 0.95 & 3691.9 & 2733.0 & $y=0.955(x)-16.75 .6$ & 1608 \\
\hline \multicolumn{6}{|c|}{ Vapor presure deficit relationships (VPD in mb) } \\
\hline Cascade Head & 0.68 & 0.192 & 0.38 & $y=1.537(x)+0.2706$ & 355 \\
\hline Waring's Woods & 0.82 & 0,242 & 0.43 & $y=[.293(x]+0.2953$ & 308 \\
\hline 5 cio & 0.66 & 0.205 & 0.11 & $y=0.727(x)+0.1345$ & 308 \\
\hline Santiant Pass & 0.84 & 0.213 & 0.33 & $y=1.001(x)+0.3 I 43$ & 334 \\
\hline Metolins & $0.8:$ & 0.236 & $0.3 \mathrm{E}$ & $y=[.409\{x\}+0.1671$ & 299 \\
\hline All sites pooiled & 0.72 & 0,269 & 0.364 & $y=1.104(x)+0.2634$ & 1608 \\
\hline
\end{tabular}

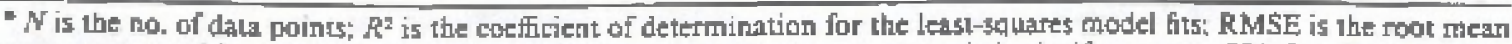

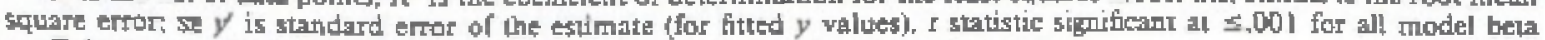
coefticients and $y$ interepts; $F$ slatistic significant at $\leq 001$ lor all regression models-

described carlier that MT-CLIM cumently doesn't handle well:

As a wider geographic test of the basic relationship betwen dew-point temperalure and 24-住 minimum temperature, we fited lintar regression rodels for daily weather data from six Naticnal Weather \$ervice sites across the continental United States equipped with bigher quality dew-point hygrometers. An annual stquerice of $365 \mathrm{~d}$ for 1984 was wed for cach of the following sites: Fairbank.5. Alaska: Seattle, Washington; Knoxville, Tennessec: Madigon. Wisconsin: Tuc\$on, Arizona; and Jacksonville, Florida. $R^{2}$ values for there regression models raged from 0.83 to 0.96 , with the exception of the drier Tucson site, whose $R^{2}$ wats 0.55. Model slopes ringed from 0.80 to 1.02 , and $y$ intercepts ranged from $-6.95101 .05{ }^{\circ} \mathrm{C}$. While acknowledging the climatological limitations of these relationships in dritr environments, we believe these cor" relations sugEest the basic soundness of the dew pointminimum temperarure relationship. Pariculary in

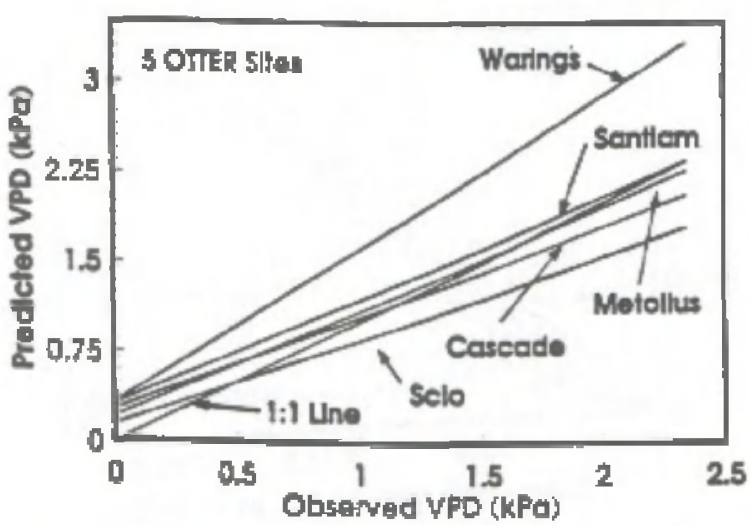

FiG. 3. Comparative plet of wapor presgure gieficil (WPD) represtion tines lor the fire sites. illusirating the arakjis of the regression slopes aboss the site pradient. more arid covironments wib lower absolute humidities, lower lowf area index (LAI) levels, and greater Elear-sky re-radiation, the dew-point temperature thay often be lower than the reported 24-h minirnum tem1peratur, and thus may never be reached (1et 1978 , Monteith and Unsworth 1990). A positive comelation between dew-point and daily minimum temperature also depends in part on dew point remaining fairly constant throughout the day; signifuant chathes in air mass moisture from advective exchange are expected to alter this basic relationship. We generally fael, however, that the correlation beween dew-point temperature and 24-h minimum temperature is sưngenough on average to be of tose in many ecological modeling applications particularly since RH (relauive humidity) sensors are so undependable. The dew-point temperature-24-h minimurm temperalure comelation we ob-

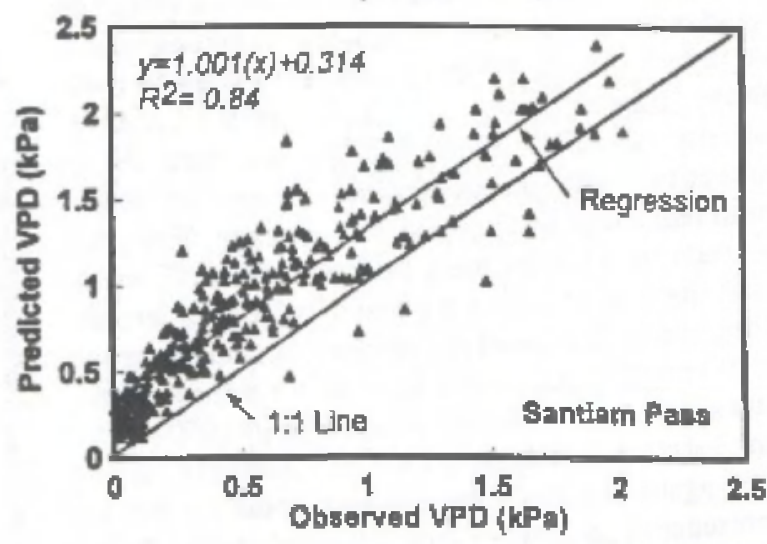

Fu. 4. Seatrofplot and retossion line or the vapor pressure deficit (VPD) model for the Santian Pass (Orepon) OTTFF site using 1989 and 1990 LTER (Long Term Eoological Reseanch) data. This regression model prowides a represtrtative example of averuge bumidiy ptormance sines data from this site did nol require screening. 


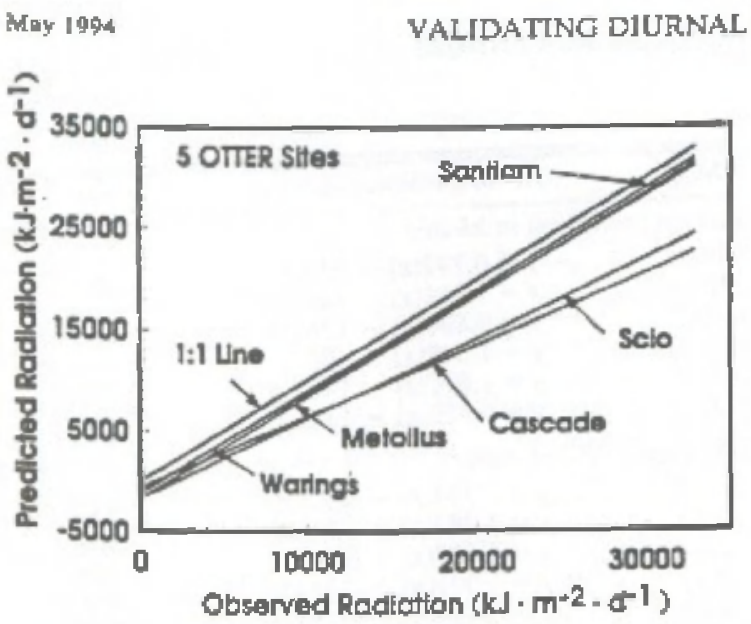

Fyg. 5. Comparatiwa plot of incident solir regression lines for the five sires, illustratine the fivigion of the tines into two bușic proups.

served may be particularly use[ul for studies emploving larger spalia] and temporal scaits, where the higher variance in diumal humidity and temperalutes may be smoothed out at larger scales.

\section{Incident solat rodiation}

Corrctations between predicied and observed incident solar radialion were gencrally constsent and high, ranging from 0.83 to 0.85 (Table 4), with $F$ statistics significant at the o0l level for all regression models. Regression slope I stitistics testing the two-tailed null hypolheses, $H_{00}$ ithal the beta coefticient aruals 0 and that the $y$ intercept equals 0 were all șignificant at the .001 level, inticating the null hypotheses should be risected. The retression model beta coeficients for the sites tended to split into two groups. with Cascade Head and Scio beta coefficients at 0.79 and $0.80_{4}$ respectively, and Metolius. Santian. Pass. and Warings Woods beta coeficients ranging from 1.01 to I.05 (Eig. 5). This division fidd not seem to oecur on a clear enYironmental fradient. and could therefore felate to local advection conditions, inversions, or random error from sampling noise. Model y intercept values were all negative, Janging from $-657 \mathrm{~kJ} / \mathrm{m}^{2}$ at the Cascade Head sine to $-2352 \mathrm{~kJ} / \mathrm{m}^{2}$ for Santiam Pass the $y$ intercepi two-talect $t$ statistical significance for all radiation regressian models was .01 or better. This statislic tests the $H_{0}$ that the $y$ intertept equals 0 , vs a $H_{\text {a }}$ that the y intercept is not equal to 0 . The scatterplot and regression line fitted for the intiden solar regerssion (Wuring's Woods site. Fig 6) shows a dense point cluster around the lower radiation range $i \approx 1000-4000$ kل $\cdot \mathrm{m}^{-2} \cdot \mathrm{d}^{-1}$ ) with a fairly balanoed cluster for higher values, again, the slight pattern herc coutd be due 10 the presence of advetion effects on sampled days. Root mean square ertor (RMSE) values for the irtident 5 phar relationships raned from $997.0 \mathrm{~kJ}$ to $4498.0 \mathrm{~kJ}$, with no appareat trend following the west-east transect gradicnt. Nomal P-P plots for the radiation data showed no serious departures form nomblity, and casewse plots of standardized radiation model residuals ws. fitted values indicated no obvious patterns in error trends. As a check on how regres.5ion VPD and solar radiation residuals might covary, plots of VPD residuats ws incident solar residuals were examined, both by site and by pooling data for all sites; no trends wert observed For either cype of plot. Overall, the consistent strength of the incident solar relationships suggesis this method Inay be suficiently robust under a t\}pical range of meteorological condizions (M. G. Ryan, personal com muricalion, J. Barron, personal communication).

\section{Conclusions}

The comparisons made here betwen obstred and estimated radiation and humidity sugest that MT. CLIM cen provide accepuble elimatology inpots for many hydrologic and ecosystem models. This approach maly prove particularly usmful for coarser spatial-scale applicarions whert absolute presision at higher spatial resolutions may not be as imporatit as an adequate chardeterization of incidemt solar radiation, diumal temperature variations, and humidity dynamics over larger regions. The problems with homidity instruments and the current lack of incident solar Tadiation dati archived daily at National Weather Service (NWS) wuather stations further supports the value of this approach. Two projects in the International Geosphere-Biosphere Program have identifit the need for a "weather generator" that takes stanchard climatological data and estimates additional meteorological variables needed by ecolopics I research. The GCTE (GIobal Change and Terrestrital Ecosytems), and the BAHC (Biospheric Aspects of the Hydrologic Cyele) projects are collaborating on developing these weather generator tools to improve both the temporal and spatial utility of clitiate data sets for ecological studieş. We think that MT-CLIM may be a usefut precursor model for this new work.

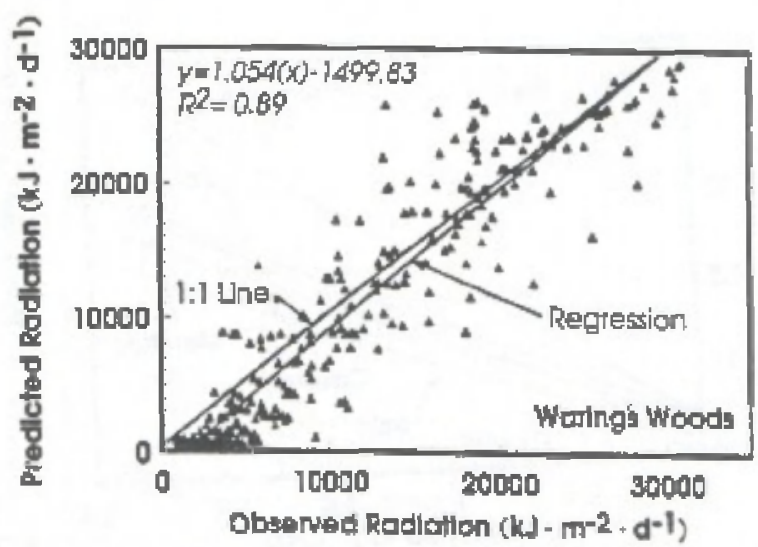

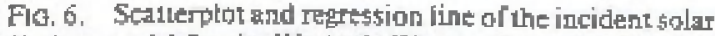
radiation model for the Wating's Woods (Corvallis, Qhegon) OTER site using 1989 and I990 LTER data. 
Aside from problems relating to the quality of input dat, a revision ofMT-CIIM should at tempt to redress earent limitations in the model extrapolation iogic. Areas meeding improvement include a provișion for adjusting between sites with significantly different air mass moisture properies (e.g., low coastal vs. dry inland sites), and a better way to generally address horizortal advection influences. Addiressing estimation errot due to cold air drainage infuences and other topographicaly drivert phenomena would probably require more radical changes, extending the model from a ome-dimensional point model to a two-dimensional spatially connected model. The terin "sparially connected" as used herc imples that the modeled point may be infuened, at the very least, by selected lasdscape characteristics of neighboring areas. If a more spatially connected approach whis pursued, a more explicit treatrnent of the topography directly irfluencing the modeled site could then be taken into account. The question of landscape scale becomes a critical one here, as a treatment of micro-topography effects would likely difter from drainage-level or even mesoscale topopraphic influerres. An additional but relgted challenge involves how valley and kababatic diurnal wind patternc might be trated in the model, if al all. Relative to the curment more simplistic MT $=C L I M$ logic such approaches would likely in volve some conscious tradeoffs in model complexity and parameterization.

The VPD relationships observed in this study, patticularly for the Cascade Head and Scio sites, were not as eondusive as we would have liked. probably due to a combiration of metecrological conditions not hartdled well in MT-CLIM as well as the selection of observed days (Fis. 2 and Table 3). Nonetheless, they may be suficiently useful for lareger sctie modeling eflorts for the reasons indicated above for solar radiation. Quality ant maintenance of hutridity sengors routinely used in the fitid were also imporant issues this study confronted, suggesting that it may be more advantageous to extrapolate irota more distant but arguably higher qualisy NWS primary weatber sustions using dew-point hygrometers than to rely on less expensive and more problemanic electro-chemical based RH instruments with shorter operational life-spans.

\section{ACRNOWLDOMENTS}

This resterch was supported by grants NAGW-252 and NAGW $\$ 892$ of the National Aerchautics and Space Administation, Earth Scjences and Appliearions Diwision, and by NSF gran BSR-8919649 to Stever W. Runлiлg Spectal tharks ga to John Ruryon of Orfigon Stale University for providjing arsisince with the observed clitrate database, and to Lars Pierce or the University of Montani School of Forestry MTSG Eor assislance and overalt guilathe in the arkalysis.

\section{LTERMTURE GTRD}

Agren, G. I. R. E. McMurtie, W. I. Parton, J. Pastor, and H. H. Shugart. 1991. State-of-the-art of models of pro-

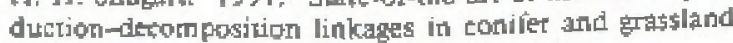
coosysters. Ecological Applicarions 1:118-13B.
Band I E. D. L Peterson, S. R. Running A. Couphlan, R Lammers. J. Durgan, and R. R. Memani. 199 T. Fortest. Lowstem processes at the watersted scaler basic for distributed simulation. Feological Modelling 56:1 1 1-196.

Hard, $L E$, and $E, F$. Wood. 1988. Strateges for large seale, distribuled hydrologic simulation. Joumal of Applied Mathemalies and Computation 27:23-37.

Barry, R. G, and R. J. Chorley- 1987. Atmosphere, whather and climate. Fifth edition. Routledge, Eondon, England

Brisıw, K L. and G. S. Campbell, 1984. On the relationship between incoming solar radialion and daily maximum and minimum temperature. Agricultural Forest Metearplogy 31:159-166.

Friend, A D. 199 I. Use of $a$ model of phouosynthesis and lear microenwironment to prectict optimal stomizial conductance and leaf nienogen partitomirge. Planc Cell and Environment 14:995-905.

Gamier, B. J., and A. Ohrum. 1968. A mathod of calcu. lating the direct stortwave radiation ineome on slopes. Journat of Appiited Mevorology 7:796-800.

Gates, D. M. 1980. Biophysical coofogy. Springer-Wertag New York. New York, USA,

Goward. S. N., R. H. Waring. D. G. Dye, and 1. Yang 1954. Exolopical remote sensing at QTTER: saiellite mactoscal a abservations. Ecolopical Applications 4:322-343r

Grantz, D. A. 1990. Plant response to dtmaspheric humidiाy, Flant Cenl and Enwtonment 13:667-679.

Hungerlord, R. D. R. R. Nernani, S. W. Runring and J. C Coughian. 1989. MTCL1M: a mounuaia mictorlimate simulation model. Resenter Paper INT-414, USDA Fotest Service, Intermountain Rescarch Station, Ogder, Utah, USA.

Hunt, E. $\mathbb{R}_{r}$ Jr. S. W, Ruming, and C. A. Federer. I 9 G. Exirapolating plan1 water flow resistances and capacitances to regional seales. Agricultural Farest Meteonology 54: $169-$ 195.

Jarris, P. G., and J. I. L Morison. 1981. The control of trisspiraton athd pholosynthesis by the stomatis Pages 247 278 in $P$. G. Javis and T. A. Mansfield, editors, Stometal physiology. Cambridge Uniwersity Press, Cambriage, Engiand.

Let, R. 2975. Forat micractimatmlogy, Cohumbia University Press, New York New York, USA.

Mason, H. L., and J. H. Langerheim. 1957. Larguage aralysis and the concepl of environment. Ecoldesy 38;325-339.

McMuruie, R. E 1985, Forest praductivity in relation to carbon partitioning and nutrient cycling: a mathematical model. Pages 194-207 in M. G. R. Cannell and J. E. Jack: gon, aditors. Attributes or trees as crop plants. Institute or Tersestrial Feolosy. Abbols Ripton. Huttington, Englatd.

Monterth. J. L. and M. H. Lnsworth. 1990. Principles of envirommental physics. Edwatd Amold. London, England. Mursy, $F$. w. 1967. On the compttation of saturation wapor pressufe. Joumal of Applied Metegrolagy $6: 203-204$.

Nemani, R. R. S. W. Running, I. Band, and D. Petersan. 1993. Reguonil hydis ecological simulation system: an illusterton of the ithegration of ecosystem models in a DIS. Pages 296-304 in M. Goodchild, B. Banks, and L Stevict. edilors Integrating GiS and environmental madeling oxFord. London. England.

Nonusich M. I. 1988. SPSS/PC+ version 3.0 update manual. SPSS Chicago, Ilinois, USA.

okc, I. R. 1987. Boundary layer climates. Second ediuion. Routledge, New York. New York, USA.

Parton. W. J.- J. W. B. Stturart, and C. V. Cole 1988. Dynamics or $C, N, F$, and $S$ in grassiand toils: a model. Eio. topehemistry 5:109-131.

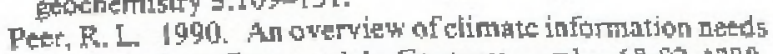
For ecological effects models. Contraci number b Atmospherte Sciences Modelling Divisian, Air Resources 
Eaboratory, Natignal Oceantc atud Almospheric Adrris. istration. Rescarch Trianele Park, Norh Carolina, USA.

Pelcrson, D. L, and $\mathrm{R}_{\mathrm{r}} \mathrm{H}$. Waring. 1994. Overwiew of the Onegon Trangect Ecosystem Rescarch project. Ecological Applications 4:2!1-225.

Reicosky, D. C, L. J. Winkelman, J. M. Baker, and D. G. Baker. 1989. Accurncy of hourly ais temperautres calctulated from daily minima and maxima. Agricultural and Forest Meleorology 46: 193-209.

Runnitg \$ W. 1984, Documentalion and preliminary ralidation of H20TRANS and DAYTRANS, two models for pretdictime transpiratian and water stress in werstem contferous forests. Reserch Papes RM1-252. USDA Fortst Serwice. Recky Mountain Fortst and Range Experimenl Slation. Fort Collins, Colorado. USA.

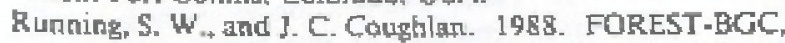
a general model of fonest expsystem prothtyes for regional applications. I. Hydrologic balance, canopy gas exehange and primary production processes. Esological Modelling 42:125-154.

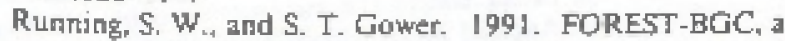
genecal madel of torest ecosystert processes for tegional apglications. II. Dynamic carbor allocation and nitrogen budgets. Tree Physiotogy 9:147-160.

Rumning, S. W. R. R. Nemari, and R. D. Hunerertord. 1987. Extrapgialion of syneptic meteorological dath in molinlaincus lerrain and is use for simluating forest cvapotrants- piration and photosynthesis. Canadian Journal or Forest Research 17:472-483.

Running, S, W., R. R. Nerani, D. L. Petersar. I. E Eand. D. F. Potts. L L. Pierce, and M. A. Sparner, 19g9. Map= ping regional forest eqapotranspiraition and phokosythesis and coupling satel] ite dala wilh ecosystem siratalation. Ecoiogy $70: 1090-1101$

Rumyon, J, R. H. Waring, S. N. Goward, and J. M. We]les 1994. Environuterlal limits on ne1 primary produclion and ljght-use efficieticy across the Oregon Itarisech. Esolog. ical Appijcarions 4:226-237.

Swilt, L W., ل $I_{1}$. 1976. Algorimm for solar radiation on mouftain slopes. Water Resources Research 12:108-112.

Wamen, \$. R., and D. L. Wance. 198\%. Remole automatic weather station for tesource and fire management agencics. Generd Itchnical Repor INT-1 16. USDA Fores! Service, Jntermountain Rescarch Slation, Ogden, Utah, USA.

Waring R. H.. K. L. Reed, and W. H. Emminghan. 1972. An environmental enit for classifying coniterous forest ecosystems. Pages 1-26-13-26 in Prowedings. Researth ㅁ. Coniferous Forest Ecosysiems-A Symposium. Belling ham, Washirgton, 2J-24 Mareh 1972. Pacife Nortiowest Forgst and Range Experimcnual Staton, USDA Forest Serrice. Pontiand, Oregoh, USA.

Waring, R. H.. and W. H. Schiesinger, 1985. Forest eco. systern, Acadertic Press, San Diego, Californin, USA 